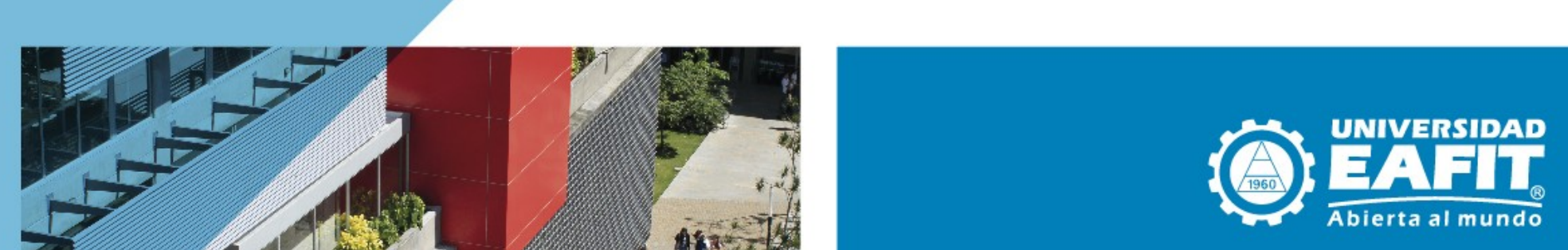

Escuela de Economía y Finanzas

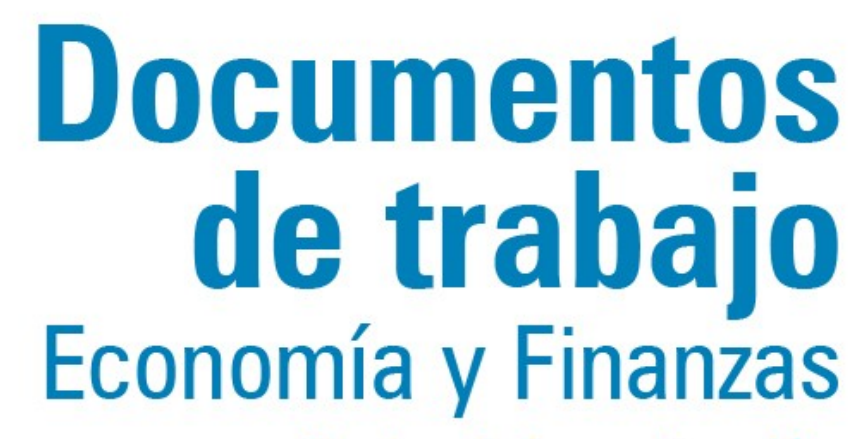

Centro de Investigación Económicas y Financieras

No. 17-18 Can IPR Affect MNE's Entry Modes? The Chilean 2017 Case

Gustavo Canavire-Bacarreza y Luis Castro Peñarrieta

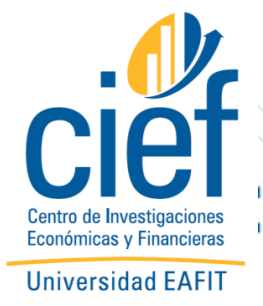




\title{
Can IPR Affect MNE's Entry Modes? The Chilean Case
}

\author{
Gustavo Canavire-Bacarreza and Luis Castro Peñarrieta *
}

\begin{abstract}
This paper analyzes the effect of stronger Intellectual Property Rights (IPR) on the entry modes chosen by MNEs in the Chilean market. MNEs can choose between exporting, introducing Foreign Direct Investment (FDI) and licensing to a domestic firm in Chile. We use plant-level data for the 2001-2007 and exploite the exogenous reform of IPR in Chile in 2005 to examine the effect of the change in IPR on the overall foreign presence in Chile, controlling for the activities of industries where high levels of technology transfer and imitation are important factors. The main results show that stronger IPR change the mode of entry chosen by MNEs. In this case, FDI is replaced by licensing. This is explained by Chile's high absorptive capacity during this period. Moreover, we test whether this effect differs across high-tech and low-tech industries and conclude that the displacement of FDI is less severe in high-tech industries.
\end{abstract}

JEL: $034,044, C 5, K 2$

Keywords: Technology Licensing, Productivity, Spillovers, Chile

\footnotetext{
${ }^{*}$ Canavire-Bacarreza: Universidad EAFIT, Medellín, Colombia, and IZA, Bonn, Germany, gcanavir@eafit.edu.co. Castro Peñarrieta: Universidad Privada Boliviana (UPB), Bolivia, luiscastro@lp.upb.edu. We would like to thank Keith Maskus, Wolfgang Keller, Scott Savage, and Thibault Fally for invaluable advice, as well as Joze Damijan and Ricardo Lopez for helpful comments. We thank Felipe Bedoya for superb research assistance.
} 


\section{Introduction}

The importance of Foreign Direct Investment (FDI) to economic growth due to the technology transfers has been documented in many studies ${ }^{1}$. Technology transfer should help reduce the gap between developed and developing countries, since there is a lack of innovation in the latter group.

In a recent trend, developing countries have introduce different measures in order to attract FDI. Many factors affect the level of FDI in a country: political stability, labor market regulations, institutional framework, and market size can all attract or deter FDI. In the current state of economic globalization, with the increasing importance of intangible assets, Intellectual Property Rights (IPR) play an important role in the decision to invest abroad ${ }^{2}$.

There is still some controversy as to the effect of stronger IPR on the welfare of the host economy. On the one hand, people advocate for stronger IPR on the grounds that they provide the protection necessary for production to shift to a developing country and thus release resources from developed countries to advance the technological frontier. On the other hand, stronger IPR's also reduce the ability of local firms in the host economy to be exposed to new technologies, and they create a monopoly effect that reduces the need to increase $\mathrm{R} \& \mathrm{D}$ in the foreign affiliate.

Awareness of the importance of IPR has increased in the last fifteen years due to the implementation of the Trade-Related Intellectual Property Rights (TRIPS) agreement in 1995 by the World Trade Organization (WTO). As stated by the WTO, "it (the agreement) establishes minimum levels of protection that each government has to give to the intellectual property of fellow WTO members".

In Chile, the first industrial property legislation was approved in 1991. There were a few modifications to the law, the most important being the approval of a new law in 2005 that made significant changes to IPR, starting with the creation of a court specific to industrial property issues.

This study analyzes the effect of strengthening IPR on inward FDI in Chile during the 2001-2007 period. In an important contribution, this paper validates and complements previous empirical studies, especially as most of them analyze a cross-section of countries rather than the evolution of firms over time. Moreover, since the study period is very recent, the implications of a change in the IPR framework could be different from the those of previous studies.

During the past two decades, Chile has been growing at a fast and steady pace. Hence, it is important to analyze the effect of stronger IPR not only on the flow of FDI

\footnotetext{
${ }^{1}$ Throughout the paper, FDI refers to inward FDI, that is, investment by a Multinational Enterprise (MNE) in a subsidiary in a host country.

${ }^{2}$ For example, Mansfield (1994) conducts a survey of 100 U.S. firms to determine the extent to which the level of IPR affects their decisions to invest in six different industries.
} 
but also on the imitative activity of the country. Stronger IPR tend to deter imitative activities and to increase the market power of MNEs in the host country.

Regarding FDI, as has been noted in many studies, once an MNE decides to service a market abroad, this can be done using three different channels: i) it can export, ii) it can shift its production (FDI), and iii) it can license its knowledge to another firm.

In a very complete survey, Park (2008) reviews the different issues related to IPR and innovation. One way to model FDI flows from developed countries (the North) to developing countries (the South) is through product-cycle models. In the basic framework, innovation occurs in the North, while there is a level of imitation in the South. Once the good is standardized, this leads to investment in and product-shifting to the South to obtain rents from lower wages. These types of models are still relevant, and a key aspect of their validity is the imitative ability of the South. Thus, any factor that affects the imitative ability of the South is likely to affect the level of FDI in the country ${ }^{3}$.

The results obtained from purely theoretical models are ambiguous and depend on the initial assumptions. Helpman (1993) and Glass and Saggi (2002) develop models that conclude that stronger IPR in the South lead to lower rates of innovation in the North, while Lai (1998) and Yang and Maskus (2001) conclude that stronger IPR in the South lead to higher levels of innovation in the North.

Therefore, it is important to validate different theoretical approaches with empirical studies in order to determine the effect of IPR on FDI, especially when there is a high volume of data with which to conduct this type of analysis.

\section{FDI in Chile}

FDI in Chile has fluctuated considerably over the last decade. This can be seen in the following figure. It is clear that there was an important inflow of FDI in the late 90s due to the privatization process in Chile.

After peaking in 1999, FDI started to decline, reaching a minimum of $\$ 2,500$ million (3.8\% of GDP). However, after this minimum, FDI started to increase again, reaching another peak in 2007 at $\$ 12,500$ million (7.6\% of GDP).

It is important to note that even though the increases in FDI that occurred after 2002 seem to be of great magnitude, as a percentage of GDP, the only large increase happened in 2004 when FDI reached $7.5 \%$ of GDP. In the other years, it averaged $5.5 \%$ of GDP.

Another important point is that Figure 1 is taken from the Balance of Payments (BOP) data, and there is no decomposition of these values by economic sector. Thus,

\footnotetext{
${ }^{3}$ For a more thorough discussion of these types of models, see, for example, Vernon (1966); Grossman and Helpman (1991); and Park (2008).
} 
Figure 1: FDI in Chile 1998-2007 (Million of US dollars)

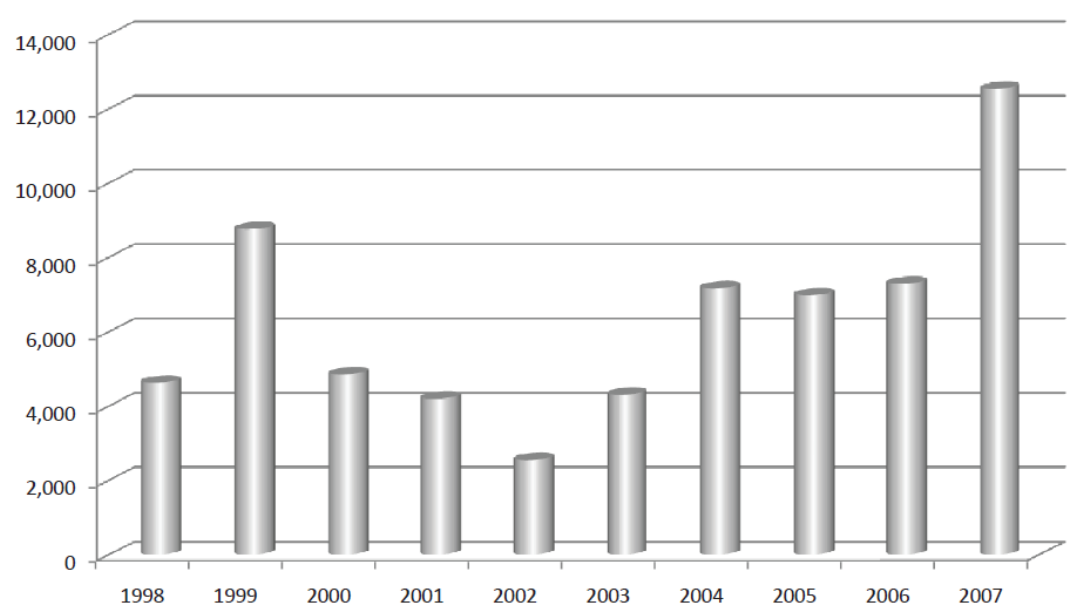

Source: World Bank. World Development Indicators.

it is possible that the changes represented in Figure 1 do not reflect FDI in the manufacturing sector, which is the focus of this paper.

Nevertheless, a government institution, the Foreign Investment Committee (FIC) addresses the portion of investors who choose to use the Foreign Investment Statute (DL600) as a means to invest in Chile ${ }^{4}$. The following figure shows the amount of FDI in Chile under DL600 by sector.

Figure 2: FDI in Chile 1998-2007 (By Sector, in Million of US dollars, under DL600)

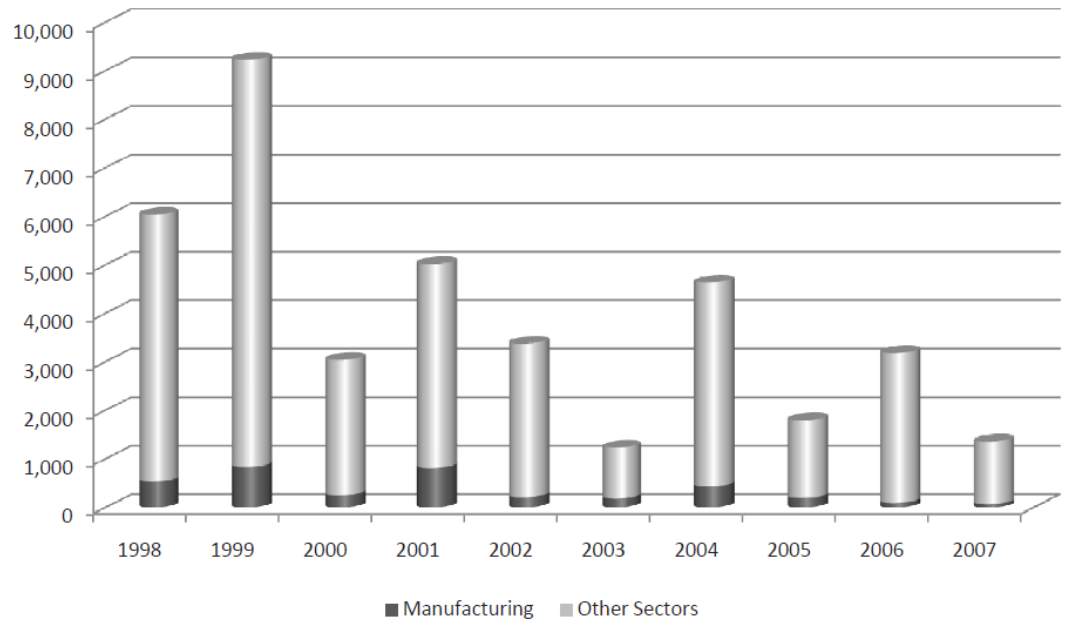

Source: Chilean Foreign Investment Committee (FIC).

As can be seen in Figure 2, FDI in Chile shows a similar pattern under DL600 and

\footnotetext{
${ }^{4}$ DL600 allows foreign investors to choose this regime when investing in Chile. Thus, investment under DL600 constitutes only part of recorded FDI in the BOP data. The difference between DL600 investment and investment in the BOP includes other capital and reinvestment.
} 
the BOP in the late 90's and early 2000s. However, the similarities end by the mid2000s. Importantly, FDI under DL600 starts to decrease after 2004. Regarding the manufacturing sector, it is very clear that FDI has significantly decreasing in the last few years, which is also shown in Table 6 (see the appendix). This suggests either that there are fewer foreign plants in the manufacturing sector or that the existing plants have significantly decreased in size.

\section{Related Literature}

Empirical studies have shed some light on the effect of stronger IPR on trade flows and FDI $^{5}$. Most studies examine FDI outflows from a developed country at the firm level (most studies use U.S. data). The greatest weakness of these studies is that, due to data constraints, they focus on cross-sectional analysis of FDI flows to different countries in a single year.

In recent years, as more data have became available, higher quality studies on FDI as the source of innovation have emerged. However, work analyzing the evolution of FDI remains scant. In particular, the existing work has been on FDI flowing out of a country (outward FDI) rather than on FDI flows into a given country (inward FDI). Moreover, there is debate about which measure of IPR strength in best ${ }^{6}$.

In one of the first attempts to study the relationship between international patent affiliation (the Paris Convention or the Berne Convention) and the affiliate level of sales, Ferrantino (1993) finds no significant evidence that affiliation affects trade or FDI.

Using U.S. data for almost 100 firms, Lee and Mansfield (1996) study the volume and composition of FDI in different countries in which there are different perceptions of IPR strength ${ }^{7}$. Their study encompasses six manufacturing industries in fourteen countries. They examine the volume of total U.S. investment in the manufacturing sector. They find that perceptions of weaker IPR lead to lower levels of FDI. Moreover, when they analyze the composition of FDI, they only use fourteen chemical firms and the ratio of FDI that was used sales and distribution to FDI used in manufacturing products. Using a Tobit model, they find that the percentage devoted to sales and distribution is positively related to weak IPR.

Braga and Fink (1998) criticize the results obtained by Lee and Mansfield (1996) based on the fact that the perception index used as a proxy for IPR strength includes other factors, such as the imitative capacity of the host country. To resolve this issue, they use a measure of IPR strength developed by Rapp and Rozek (1990) and a larger sample of countries; nevertheless, their results are in line with those ofLee and Mansfield (1996).

\footnotetext{
${ }^{5}$ For a discussion of the relation between trade and IPR, see Maskus and Penubarti (1995).

${ }^{6}$ The different measures of IPR will be discussed in the empirical approach section.

${ }^{7}$ They use the perceptions of IPR strength collected by Mansfield (1994).
} 
Nunnenkamp and Spatz (2004) use U.S. data disaggregated at the industry level for more than one hundred countries and different measures of IPR strength. The hypothesis they test relies on the fact that FDI flows to different countries depend on industry and host- country characteristics. They also consider different dependent variables to test whether stronger IPR affect the quantity and quality of FDI.

They use the industry FDI stocks of 166 countries. They also have data on sales, value added, employment, total employee compensation, exports and imports, local R\&D expenditures and license fees paid to the U.S. for a subsample of countries (58).

A new feature of this study is that they compare two different years, 1995 and 2000. They focus on seven manufacturing industries in 1995 and five in $2000^{8}$. They supplement these data with country characteristics (GDP per capita and average years of schooling).

To measure IPR, they follow Ginarte and Park (1997), and IPR strength is measured by the World Economic Forum $(\mathrm{WEF})^{9}$. The specifications include traditional FDI determinants as controls, such as GDP per capita, population, distance from the U.S. and two institutional indicators. To analyze FDI quality, they examine host R\&D expenditures, value added and exports of the affiliate.

They find that IPR are not significant when host-country characteristics are not taken into account. They then interact host-country characteristics with the IPR measures and find that IPR are only significant when host-country characteristics are taken into account. Moreover, they find no significant differences when using different IPR measures. They find that stronger IPR increase the quality of FDI in the host countries (as measured by R\&D, value added, and exports of the affiliate).

In another study, Smith (2001) examines the effect of foreign patent rights on U.S. exports, sales in the host country and licenses. A new approach is used, since the effect of IPR on the three modes used by MNEs (exports, sales by affiliates, and licensing) are examined simultaneously. The data include 50 countries in 1989.

Smith (2001) tests whether stronger IPR increase exports, sales via affiliates and licenses in order to determine whether the market expansion effect or the market power effect is stronger ${ }^{10}$. Other tests examine whether strong IPR lead to knowledge transfer to the host country and whether the transfer of knowledge occurs within the same

\footnotetext{
${ }^{8}$ In 1995, the industries are food, chemicals, metals, machinery, electronic equipment, transport equipment and other manufacturing. In 2000, the industries are food, chemicals, metals, machinery and electronic equipment, and transport equipment.

${ }^{9}$ The Ginarte-Park IPR strength measure is constructed quinquennially using five categories of patent laws to form an index that ranges from 0 to 5 . The WEF measure will be explained in more detail later.

${ }^{10}$ The market expansion effect refers to higher production (through exports, sales, or licenses) in the foreign market, since the technology being transferred is better protected. The market power effect refers to the fact that stronger IPR confer more market power on the MNE in the host country, reducing the level of production in the foreign market.
} 
$\operatorname{firm}^{11}$.

The findings show a positive relation between IPR strength and the sales of U.S. affiliates in a host country. There is also a positive effect of IPR on licenses granted to foreign firms. However, the level of exports is not significantly affected by IPR. This leads to the conclusion that strong IPR exert a market expansion effect in the host country rather than a market power effect. Moreover, the effect is larger in countries that have high imitative capacity.

Additionally, stronger IPR increase the location advantage for the MNE, since there is a stronger effect on licenses than on affiliate sales. Thus, it is possible that MNEs reduce their level of FDI and use licensing instead.

The most relevant study using foreign data is Javorcik (2004b), which focuses not only on the effect of stronger IPR on inward FDI but also on the composition of FDI in twenty-four economies in Eastern Europe and the former Soviet Union.

To test these hypotheses, they examine the effect of stronger IPR in tech-intensive sectors - the same sectors used in Mansfield (1994). The second hypothesis tests whether the investor sets up production facilities or only engages in distribution/advertising activities, thus differentiating between "productive" FDI and FDI that does not increase productivity and is solely used to increase sales.

She finds that weaker IPR have two effects, one direct effect deterring FDI and a compositional effect increasing the investment in distribution projects rather than local production or R\&D.

In a more recent study, Branstetter et al. (2006) analyze the effect of IPR reforms in sixteen countries during the 1982-1999 period. Using U.S. firm-level data, they analyze the effects of stronger IPR measures on international technology transfer.

They conclude that royalty payments for technology transferred increased at the time of the reform. Additionally, R\&D expenditures in the host country increased, especially for firms that use patents extensively. This study represents a breakthrough in the literature, since panel data is required to perform a competent analysis.

A more complete study by Branstetter et al. (2007)followed ${ }^{12}$. Using the same data as Branstetter et al. (2006), this study is the closest in spirit to the hypotheses tested for the Chilean economy in this paper.

They develop a theoretical model that predicts that stronger IPR measures lead to higher FDI due to the shifting of production to affiliates in developing countries. This, in turn, frees resources in developed countries so that more innovation can take place.

They test the model empirically by examining production-shifting to developing countries (increasing the scale of production by affiliates). They approach this problem

\footnotetext{
${ }^{11}$ If sales by affiliates are highly affected by the reform, then knowledge transfer occurs within the same firm, whereas if the reform affects licenses, then knowledge is transferred to an external firm.

${ }^{12}$ Hereafter, BFFS.
} 
using the following equation:

$$
S_{i l t}=\alpha_{0}+\alpha_{i l}+\alpha_{t}+\beta_{0} y_{j t}+\beta_{1} P_{i t}+\beta_{2} H_{j t}+\beta_{3} R_{j t}+\beta_{4} R_{j t} * T e c h_{i l}+\varepsilon_{i t}
$$

where $i$ indexes the affiliate's parent firm, $l$ the affiliate, $j$ the host country, and $t$ the year. The dependent variable is a measure of the scale of the affiliate $S_{i l t}$; they use capital stock, employment compensation, use of technology from the parent firm and R\&D expenditures. They control for affiliate fixed effects, time fixed effects and country-specific time trends. $P$ and $H$ are parent characteristics and host-country characteristics, respectively ${ }^{13}$.

In equation $1, R_{j t}$ is a reform dummy variable that takes the value zero before the reform and one afterward. Tech $-i l$ is a dummy variable that equals one for affiliates with high technology transfer from the parent and zero for low technology transfer ${ }^{14}$.

They find that MNE's increase their capital stock and employment compensation but reduce royalties paid after IPR reforms. These results are compatible with the idea that there is production-shifting to developing countries.

Another hypothesis tested in their study is whether the increase in production by MNEs offsets the reduction in the production of imitators in developing countries. This is done by examining industry-level outcomes before and after the reform. The specification in this case is:

$$
V A_{i j t}=\alpha_{0}+\alpha_{i j}+\alpha_{t}+\beta_{0} y_{j t}++\beta_{1} H_{j t}+\beta_{2} R_{j t}+\beta_{3} R_{j t} * I n d T e c h_{i}+\varepsilon_{i t}
$$

In this case, the dependent variable is the value added in industry $i$ in country $j$ and year $t$. The IndTech dummy is equal to one for technologically intensive industries ${ }^{15}$. Using this specification, they find that "output expansion is concentrated in technology intensive industries" ${ }^{16}$.

Both studies, (Branstetter et al., 2006, 2007), include the Chilean IPR reform of 1991. However, they do not take into account the more recent reform in 2005. Moreover, a limitation of their analysis is that they use only statutory measures of changes in $\mathrm{IPR}^{17}$. This method does not allow for lagged implementation of new regulations.

\footnotetext{
${ }^{13}$ Their results can be viewed in appendix C (Table 8).

${ }^{14}$ To assign a value for Tech, they use the median license payments from affiliates to parent firms over four years prior to a particular reform. Affiliates with license payments above the median are assigned a value of one; those below the median, zero.

${ }^{15}$ The industries included are electrical machinery, industrial chemicals, other chemicals, professional and scientific equipment, and transportation equipment.

${ }^{16}$ The results can be viewed in appendix C (Table 9).

${ }^{17}$ This means that they use a dummy variable for reform, implying that regulatory changes and enforcement occur instantaneously.
} 
The main contribution of this paper is to clarify the relevance of a change in IPR on FDI flows in Chile. Thus, it is important to validate the results found by BFFS after more than a decade of rapid economic growth. Moreover, it is important to determine the reaction of the economy as a whole to stronger IPR, since imitative activity may have increased in the past decades. It is also possible that MNEs now prefer granting licenses to investing abroad.

It is important to validate the results of other empirical studies because, in most cases, they examine older data from before the implementation of TRIPS by WTO members. Thus, the results of BFFS come from economies in which a full IPR structure was not yet implemented.

Another important feature of this study is the use of a very extensive survey of the Chilean manufacturing sector. The data come from the Chilean Annual Manufacturing Census (ENIA), which includes all establishments with 10 or more workers. This allows for a thorough analysis of the manufacturing sector using panel data. This dataset also allows the assessment of entry-exit decisions by foreign firms. This type of survey has not yet been used extensively, since most previous studies have conducted only cross-sectional analyses.

\section{Data}

The plant-level data used in this series of studies come from the Chilean Encuesta Nacional Industrial Anual (ENIA) ${ }^{18}$. The survey is conducted by the National Statistics Institute (INE) of Chile and covers all establishments (plants) with ten or more workers. The years covered by this study are 2001-2007.

Previous versions of this census have been used by Pavcnik (2002) and Lopez (2008), among others. However, they use previous waves of the census. One study that uses the census for the 2001-2006 period is Gibson and Graciano (2011).

The unit of observation is the establishment's (plant). There are firms that only have one plant; however, other firms have multiple plants that are integrated either vertically or horizontally (multi-plant and multi-activity firms).

In the case of multiple plants, the survey includes each plant that belong to a firm. Each plant has its own ID number for statistical secrecy reasons; thus, it is not possible to identify which plants belong to a given firm ${ }^{19}$. Thus, each plant has a unique ID number that allows its performance to be tracked over time, permitting longitudinal studies. In the present paper, the terms "plant" and "firm" will be used interchangeably.

To classify the economic activity of each plant, the International Standard Industrial Classification of All Economic Activities (ISIC) revision 3 produced by the United

\footnotetext{
${ }^{18}$ This is a national survey of the manufacturing sector.

${ }^{19}$ This could be a problem if the majority of firms are multi-plant; however, as noted by Pavcnik (2002), in a previous version of this dataset, approximately $90 \%$ of firms have one plant.
} 
Nations was used ${ }^{20}$. Economic activities are considered at the four-digit level ${ }^{21}$.

\section{IV.I Data Cleaning}

The original dataset contains 37,307 observations. The first thing to note about the dataset is that starting in 1974, Chile was divided into 13 regions. However, in 2007, two regions were split, Tarapacá became Arica y Parinacota and Tarapacá; and Los Rios became Los Rios and Los Lagos. In order to maintain the consistency of the dataset, the 1974 division is maintained throughout the study period.

Next, since all the monetary variables in the dataset are in current pesos, it is necessary to deflate them into real pesos. Two different deflators are used. This study relies on the estimation of Total Factor Productivity (TFP); thus, for all variables that enter into the estimation of TFP, such as sales, we use a 4-digit deflator specifically designed by the INE for this survey. For variables that have a broader macroeconomic meaning, such as the value of licenses paid or wages, it makes more sense to use a more general deflator. For these variables, we use a more encompassing deflator, the GDP deflator, provided by the Central Bank of Chile ${ }^{22}$.

Some observations were purged in the data cleaning process. First, we dropped one observation for which the value added for the firm was extremely high in one year. It is also important to note that even though there might be some negative value added figures (due to the fact that it is calculated as the production value minus intermediate goods), those observations remain in the dataset. This could be a concern for the TFP estimation; however, as will be clear in the estimation section, we use revenue (sales) for TFP estimation instead of value added.

The rest of the observations that are excluded are firms that change industries or regions (locations) during the study period. Even though it could be argued that there is a loss of information in this case, the counter argument is twofold. First, the number of observations lost is not extremely high, and second, when estimating a model using fixed effects, the main assumption is that these fixed effects capture all the characteristics of a firm that do not change over time. Thus, a change in industry or region would invalidate the interpretation of the results ${ }^{23}$. The final dataset has 36,026 plant-year observations in 111 industries.

${ }^{20}$ See http://unstats.un.org/unsd/cr/registry/regcst.asp?cl=2 for more details.

${ }^{21}$ The covered industries, in terms of ISIC (Rev.3) codes, are 17, 18, 19, 20, 21, 22, 24, 25, 26, 27, $28,29,30,31,32,33,34,35$, and 36. The ISIC (Rev.3) codes for the manufacturing sector range from 15 to 36 . Industries 16 (tobacco) and 23 (coke, refined petroleum products and nuclear fuel) have no observations in the dataset.

${ }^{22}$ The deflator used in this series of studies is the 4-digit deflator for TFP estimation, although we compare the results obtained from using the GDP deflator, the 2-digit deflator and the 4-digit deflator for variables such as license payments.

${ }^{23} \mathrm{~A}$ more detailed explanation will be provided in the empirical section. 


\section{IV.II Descriptive Statistics}

Table 1 presents descriptive statistics for the key variables. It is important to note that most of the capital stock is held by domestic plants, while foreign firms hold only $31 \%$ of the capital stock, on average ${ }^{24}$. However, this is a very high percentage compared to the percentage of foreign firms.

Table 1: Descriptive Statistics for Key Variables (36,026 Obs.)

\begin{tabular}{lllll}
\hline \hline Variable & Mean & SD & Min & Max \\
\hline Capital Stock & 2,611 & 26,352 & 0 & $2,140,000$ \\
\% Domesic Capital & 95 & 20 & 0 & 1001 \\
\% Foreign Capital & 5 & 20 & 0 & 100 \\
Value Added & 3,052 & 26,766 & 118,000 & $1,860,000$ \\
Sales Of Production & 4,960 & 37,206 & 0 & $1,810,000$ \\
Payments for Licenses And Foreign Assistance & 8 & 152 & 0 & 11,864 \\
Income Due To Exports & 1,779 & 17,771 & 0 & $1,020,000$ \\
Number of Skilled Workers & 15 & 58 & 0 & 2,691 \\
Skilled/Unskilled workers ratio & 1 & 4 & 0 & 287 \\
Skilled/Total workers ratio & 0 & 0 & 0 & 1 \\
\hline \hline
\end{tabular}

Note: All monetary values are in 2003 Million Pesos. Value added has negative values due the calculation method, the difference between gross production value and intermediate consumption.

To determine which firms are considered foreign, we used a $10 \%$ capital rule (i.e., if the foreign capital holdings of the establishment exceed $10 \%$, it is considered foreign). The resulting differentiation is presented in table table 2.

Table 2: Number of Firms by Type of Ownership (10\% capital rule)

\begin{tabular}{llll}
\hline \hline Owner & Freq. & Percent & Cum. \\
\hline Domestic & 33,992 & 94. & 94. \\
Foreign & 2,034 & 6. & 100 \\
Total & 36,026 & 100 & \\
\hline \hline
\end{tabular}

Moreover, it is possible to analyze the number of firms that operate only in the domestic market, those that sell to the domestic market and export, and those that only export. This distribution is depicted in table table 3.

When analyzing the dynamics of foreign presence in Chile, one striking feature is depicted in the figure below. There is a drastic decline in the number of foreign plants after 2004, and the 2007 level is even lower than that in 2001.

\footnotetext{
${ }^{24}$ This calculation is not shown in table table ??, but it is available upon request.
} 
Table 3: Distribution of Firms according to Market Service

\begin{tabular}{lrrr}
\hline \hline Market & \multicolumn{1}{c}{ Freq. } & Percent & Cum. \\
\hline Non-exporter & 28,641 & 79.5 & 79.5 \\
Domestic and Ecporter & 7,101 & 19.71 & 99.21 \\
Exporter & 284 & 0.79 & 100 \\
Total & 36,026 & 100 & \\
\hline \hline
\end{tabular}

Figure 3: Number of Foreign Plants

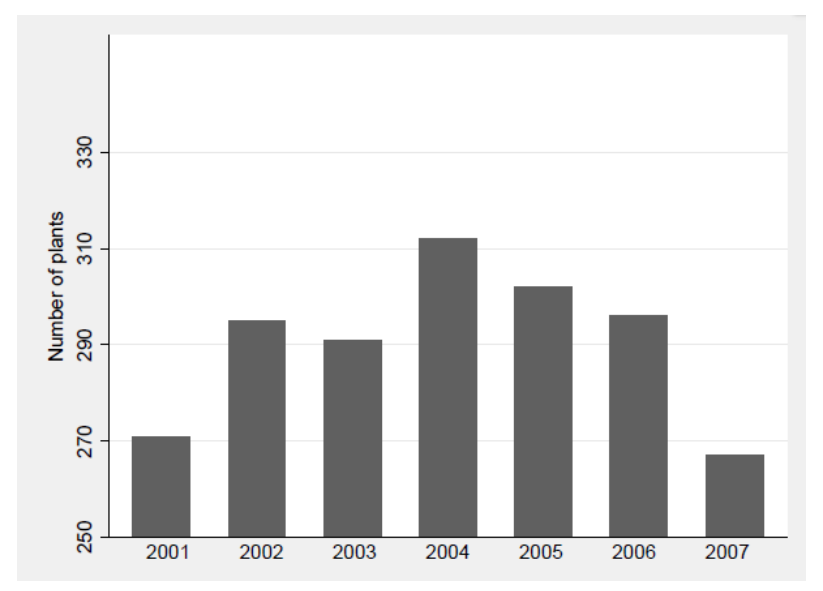

Figure 3 above also illustrates this fact: it seems that FDI in the manufacturing sector has been decreasing steadily in the last few years.

To estimate TFP, the data have been grouped at the 2-digit ISIC level. To better understand the distribution of the data, consider the number of observations and the description of each 2-digit ISIC group presented in table table 7 of the appendix.

To better analyze the dynamics of domestic and foreign firms, as well as of entry and exit, it is possible to construct transition tables to quantify the entry and exit of foreign plants. The average transition matrix for any two years in the 2001-2007 period is depicted in table table 4 .

This matrix is interpreted as follows. Say we take the Domestic-Domestic cell in the matrix, which shows that for the entire period, 25,592 firms were domestic in period t and remained domestic in period $t+1$. The Foreign-Domestic cell shows how many plants changed from foreign to domestic, and so on. The Enter row shows how many plants entered the Chilean market in $t+1$, while the Exit column shows how many plants exited in period t.

There are a few important things to note from this transition table. First, it is clear that the number of domestic firms has decreased in this period (this is due mostly to a decrease in the number of firms in 2007). At the same time, the number of foreign firms has stayed relatively constant $(1,767-1,763)$. Second, the previous comment is 
Table 4: Transition Matrix for 2001-2007

\begin{tabular}{cccccc}
\hline \hline \multicolumn{5}{c}{$2001-2007$} \\
\hline \multirow{5}{*}{ Period t+1 } \\
Period t $\mathrm{Domestic}$ & Foreign & Exit & Total \\
& Domestic & 25,592 & 129 & 3,695 & 29,416 \\
& Foreign & 167 & 1,419 & 181 & 1,767 \\
& Enter & 3,546 & 215 & 0 & 3,761 \\
& & & & \\
& Total & 29,305 & 1,763 & 3,876 \\
\hline \hline
\end{tabular}

confirmed by the number of exits for domestic firms $(3,695)$ and the number of entrants $(3,546)$.

However, a note of caution is needed here, since the total number of plants (domestic and foreign) has decreased since 2004. Therefore, the previous conjecture should be tested more rigorously.

It is possible to decompose the above transition matrix into the periods before and after the IPR reform in 2005. The resulting transition matrices are depicted in table table 5 .

Table 5: Transition Matrices (Before and After IPR Reform)

\begin{tabular}{|c|c|c|c|c|c|}
\hline \multicolumn{6}{|c|}{ 2001-2004 (BEFORE) } \\
\hline \multirow{6}{*}{ Period t } & & Period t- & & & \\
\hline & & Domestic & Foreign & Exit & Total \\
\hline & Domestic & 16,981 & 83 & 2,571 & 19,635 \\
\hline & Foreign & 117 & 937 & 115 & 1,169 \\
\hline & Enter & 3,546 & 215 & 0 & 3,761 \\
\hline & Total & 20,644 & 1,235 & 2,686 & \\
\hline \multicolumn{6}{|c|}{ 2005-2007 (AFTER) } \\
\hline \multirow{6}{*}{ Period $t$} & & Period $t$ - & & & \\
\hline & & Domestic & Foreign & Exit & Total \\
\hline & Domestic & 8,611 & 46 & 1,124 & 9,781 \\
\hline & Foreign & 50 & 482 & 66 & 598 \\
\hline & Enter & 690 & 35 & 0 & 725 \\
\hline & Total & 9,351 & 563 & 1,190 & \\
\hline
\end{tabular}

The most important thing to note from these matrices is the change in the entry/exit ratio. Before the IPR reform, this ratio was 1.87 , while after the reform, the ratio decreased substantially to 0.53 . Thus, after the reform, more foreign firms were exiting 
the market than before. This finding was also reflected in figure 3 .

\section{Measures of IPR}

Two different measures of IPR are used in this study, a dummy variable at the time of the change and the Fraser index.

The dummy variable takes the value one on and after the year of the reform (2005) and zero otherwise. This is the type of measure used by Branstetter et al. (2007).

However, since this change does not happen overnight, it is also useful to take into account a survey measure related to IPR and property rights in general. Thus, the second measure of protection comes from the Fraser Institute's Economic Freedom in the World report. In this case, the following question is asked: "Property rights, including over financial assets, are poorly defined and not protected by law $(=0)$ or are clearly defined and well protected by law $(=10)^{25 "}$.

The two different measures can be viewed in the graph below. Note that the Fraser index and the dummy measure follow the same trend, so we should not expect differences to stem from using either measure.

Figure 4: IPR Strength Measures

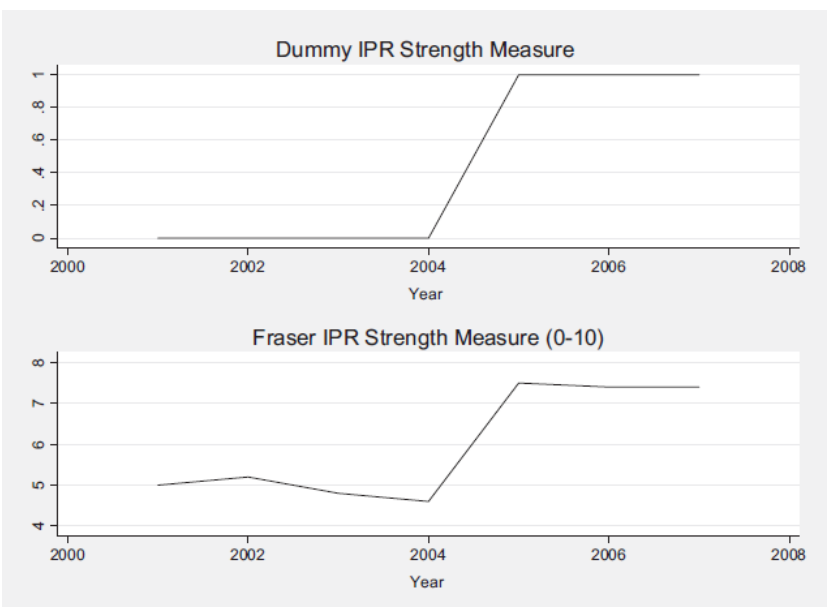

\section{Empirical Approach}

Since the IPR law change constitutes a treatment-effect type of estimation, we use a Difference-in-Differences (DD) approach, where the main assumption is that firms that

\footnotetext{
${ }^{25}$ The formula used by the Fraser Institute is based in the index created by another institution, the World Economic Forum, in its Global Competitiveness report. The relation used is: $E F W i=$ $[(G C R i-1) / 6] * 10$.
} 
were technologically intensive before the reform exhibit the same pattern in inward FDI as firms that were not "technologically intensive" in the absence of a reform.

As stated above, changes in FDI can occur at either the extensive or the intensive margin. Regarding the intensive margin, it is possible to analyze the expansion of the production of foreign plants in the entire period in a given industry. As explained in the data section, when talking about the extensive margin, changes come from two sources: $i$ ) new foreign or domestic firms that enter the Chilean economy and $i i$ ) firms that were domestic at the beginning of the sample and, at some point, started to have foreign holdings.

\section{Testable Hypotheses}

\section{VII.I Foreign Presence}

The first testable hypothesis follows Branstetter et al. (2007) in the sense that it is important to capture whether stronger IPR lead to an increased overall presence of foreign firms in Chile at the industry level.

Thus, some measure of the foreign presence, such as the capital stock, in the industry is needed. In this sense, an indicator in the spirit of import penetration would be the "foreign penetration" of a given industry, which can be constructed for each industry as follows:

$$
\text { fdikstock }_{j}=\frac{\sum_{j}^{f}}{\sum_{j}^{f+d}}=\frac{\text { Sum of capital stock for foreign plants }}{\text { Sum of capital stock for all plants }}
$$

Therefore, the specification that could be used in order to test for changes in the "FDI penetration" could take the following form:

$$
\text { fdikstock }_{j t}=\alpha_{j}+t+\beta_{0} I P R_{t}+\beta_{1} I P R_{t} * T e c h_{j}+\beta_{2} X_{j}+\varepsilon_{j t}
$$

where $j$ indexes each industry and $t$ the year; $\alpha_{i}$ captures industry fixed effects, and $t$ is a time trend; IPR $R_{t}$ is the strength of IPR; Tech $j$ is a dummy variable that takes the value one if the firm is technologically intensive and zero otherwise; and $X_{j}$ are the controls. $^{26}$

Moreover, since the transition matrices and the overall data on FDI in the manufacturing sector seem lower after 2005, it is plausible that the foreign presence is being replaced by domestic firms. This would lead more foreign plants to exit the market and could increase the amount that plants pay for licenses and foreign technical assistance. This can be tested using the following specifications:

\footnotetext{
${ }^{26}$ The generation of the Tech $i$ dummy will be explained later. The controls include average size and the market where the industry sells its product.
} 


$$
\text { kstock }_{j t}=\alpha_{j}+t+\beta_{0} I P R_{t}+\beta_{1} I P R_{t} * \text { Tech }_{j}+\beta_{2} X_{j}+\varepsilon_{j t}
$$

where the subscripts are similar to those in equation (4).

\section{VII.I.1 Generating the test and comparison groups}

To obtain a valid interaction term in equation 4 , it is crucial to have valid test and comparison groups. Thus, it is necessary to distinguish between technologically intensive

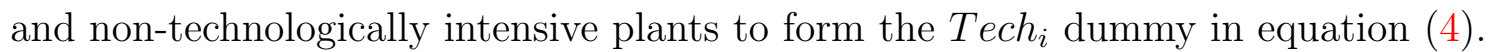

This can be done by letting each plant be technologically intensive if it belongs to industries that are considered high-tech in other countries. In this case, the Compendium of Patent Statistics elaborated by the OECD is used to define high-tech industries. ${ }^{27}$ The technologically intensive industries using the ISIC Rev.3 classification (at the 2-digit level) are medical, precision and optical instruments; radio, television and communication equipment; office accounting and computing machinery; and pharmaceuticals. $^{28}$

The descriptive statistics for each group of foreign plants are presented in table 8 in the appendix. First, note that the stock of capital and value added are lower for tech-intensive plants. This could be due to size issues with the plants (e.g., non-tech plants might need more buildings in the manufacturing sector). Nevertheless, it is clear that payments for licenses, skill intensity and skill ratio are higher for high-tech plants, which is expected. Second, regarding the remaining variables, the values are similar for both groups, which is also expected.

\section{VII.II Ownership of Firms}

The second testable hypothesis concern the effect of stronger IPR on the probability of foreign ownership of the plant. In this case, it is possible to use a random effects probit model to examine the effects of the level of IPR as well as the effects on technological intensive plants. Ownership, as previously defined, relies on a $10 \%$ capital rule, providing a categorical variable that equals one when the plant is foreign and zero when it is domestic. The specification in this case would take the form:

$$
\text { owner }_{i t}=\alpha_{0}+\beta_{1} I P R_{t}+\beta_{2} I P R_{t} * \text { Tech }_{i}+\beta_{3} \text { Tech }_{i}+\beta_{4} X_{i t}+\varepsilon_{i t}
$$

where $i$ indexes each plant and $t$ the year; $I P R_{t}$ and $T e c h_{i}$ are defined as in equation equation (6); and $X_{t}$ is a set of controls at the country level, such as the exchange rate

\footnotetext{
${ }^{27}$ It is important to note that the patent classification is not fully compatible with the ISIC industry classification, but the OECD based their classification on the comparison of Scmoch et al. (2003).

${ }^{28}$ Since there is no pharmaceuticals industry in the ISIC Rev.3, this category is replaced by industrial chemicals and other chemicals.
} 
and inflation. Controls at the plant level, such as plant size in the market of service, are also included.

\section{Preliminary Results}

\section{VIII.I Foreign Presence}

The first test is conducted with the full sample. To understand intuition behind the results, we can consider the total "foreign penetration" index (see figure 5). We observe that foreign presence decreases after 2005 in the tech-intensive sectors and increases slightly for the remaining sectors. This is in line with the hypothesis that foreign plants are being replaced with domestic ones, especially in the tech-intensive sectors, resulting in more licensing payments.

This should be reflected by a negative coefficient on the interaction term in equation 4. In a similar fashion, when looking at the Index of License Payments (figure 6), the upward trend in the technological sector suggests that there is more licensing after 2005 in the high-tech sectors. Thus, we would expect a positive sign on the interaction term in equation equation (5).

The results obtained after using specifications 4 and equation (5) are depicted in Table 9 (see the appendix). As expected, the interaction term with IPR has a negative effect on the level of foreign presence. Moreover, the effect on the level of licensing is positive and significant. This supports the hypothesized reduction in the number of foreign plants and increase in licensing in Chile after the reform ${ }^{29}$.

Figure 5: Foreign Presence Index

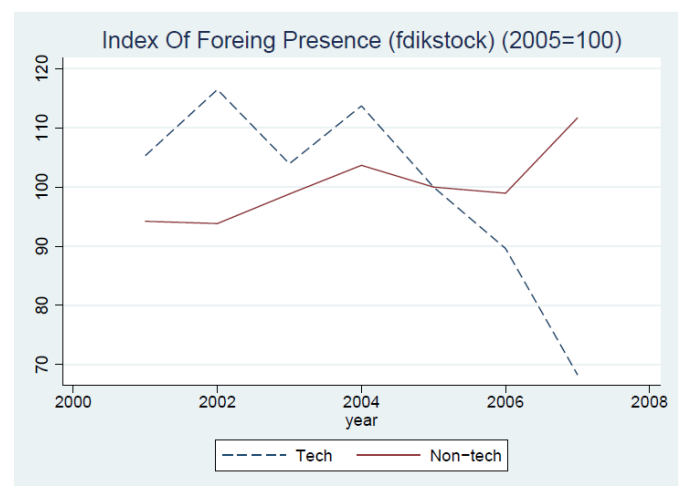

\footnotetext{
${ }^{29}$ It is important to note that no controls have been included in this specification, since the industry and time dummies control for anything that happens at the industry or country level. However, the results are robust to the inclusion of variables that vary at the country level. Additionally, the number of observations is not a multiple of the number of industries because the panel is unbalanced such that some industries are not present in some years.
} 
Figure 6: License Payments Index

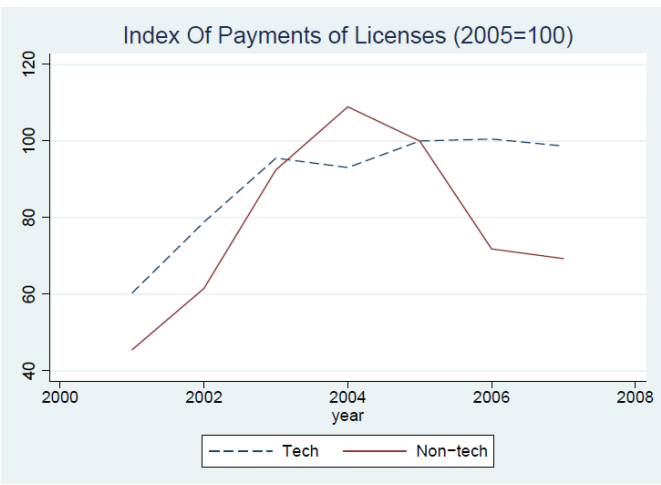

When using the random effects probit (table 10), it is possible to show that higher levels of IPR have a negative effect on the probability of being a foreign plant. This is highly significant for the Fraser Institute index and the dummy measure of IPR.

Moreover, the effect tends to be lower for high-tech plants, since all the interaction terms are positive and significant. This supports the hypothesis depicted in the transition matrix that with stronger levels of IPR, the probability of being a foreign-owned plant is significantly reduced. Additionally, foreign owners tend to 'stay' in the hightech sectors relative to low-tech sectors. This could be due to the fact that Chilean plants are capable, at least in the last few years, of reproducing whatever the foreign plant was producing.

\section{Conclusions}

The importance of FDI for economic growth has been emphasized throughout the economics literature. Moreover, developing countries rely on FDI as a source of technology transfer and innovation. Thus, it is important to clarify the most effective channels through which a developing country can benefit from the technology advancements of developed countries.

In the present state of globalization, IPR affect the decisions of MNEs to invest abroad. This has been shown in previous studies that find that stronger IPR lead to higher FDI and higher quality FDI being sent abroad.

However, not many studies focus on inward FDI. In that sense, the present study constitutes a contribution to the literature. Moreover, we use different measures of IPR in order to validate the results, and the extensive nature of the data allows for the testing of hypothesis that could previously only be partially performed.

Preliminary results show that, despite previous studies, stronger IPR led to lower levels of FDI in Chile during the 2001-2007 period. One of the main causes for the reversal of the results presented in Branstetter et al. (2007), for example, is that Chilean 
firms have changed considerably in the last decade, increasing their imitative capabilities and being able to produce goods that were not previously produced by local firms.

When taking these factors into account, it is possible to test whether foreign firms have left the market since the reform. The results are consistent with the body of literature arguing that licensing overtakes FDI once an IPR threshold is reached.

The relevant IPR threshold and the effects of IPR reform on licensing do not depend entirely on the IPR level per se but depend most importantly on the level of development of the host country and its ability react to changes in IPR. Moreover, it is possible to examine whether spillover effects from foreign firms to domestic firms occurred after the reform and whether the remaining domestic firms benefitted from greater access to technology that could possibly be imitated.

\section{References}

Acharya, R. C. and Keller, W. (2009). Technology transfer through imports. Canadian Journal of Economics/Revue canadienne d'?conomique, 42(4):1411-1448.

Ackerberg, D., Caves, K., and Frazer, G. (2006). Structural identification of production functions. Unpublished manuscript, UCLA Economics Department.

Aitken, B. J. and Harrison, A. E. (1999). Do domestic firms benefit from direct foreign investment? evidence from Venezuela. The American Economic Review, 89(3):605618.

Alfaro, L., Chanda, A., Kalemli-Ozcan, S., and Sayek, S. (2006). How does foreign direct investment promote economic growth? Exploring the effects of financial markets on linkages. Working Paper 12522, National Bureau of Economic Research.

Alvarez, R., Crespi, G., and Ramos, J. (2002). The impact of licenses on a "Late starter" LDC: Chile in the 1990s. World Development, 30(8):1445-1460.

Arellano, M. and Bond, S. (1991). Some tests of specification for panel data: Monte Carlo evidence and an application to employment equations. The Review of Economic Studies, 58(2):277?-297.

Arnold, J. M. (2005). Productivity estimation at the plant level: A practical guide. Unpublished manuscript, 27.

Blalock, G. and Gertler, P. J. (2008). Welfare gains from foreign direct investment through technology transfer to local suppliers. Journal of International Economics, 74(2):402-421.

Blundell, R. and Bond, S. (1998). Initial conditions and moment restrictions in dynamic panel data models. Journal of econometrics, 87(1):115?-143. 
Braga, C. A. and Fink, C. (1998). The relationship between intellectual property rights and foreign direct investment. Duke J. Comp. \$0 Int'l L., 9.

Branstetter, L., Fisman, R., Foley, C. F., and Saggi, K. (2007). Intellectual property rights, imitation, and foreign direct investment: Theory and evidence. Working Paper 13033, National Bureau of Economic Research.

Branstetter, L. G., Fisman, R., and Foley, C. F. (2006). Do stronger intellectual property rights increase international technology transfer? Empirical evidence from US firm-level panel data. Quarterly Journal of Economics, 121(1):321-349.

Cameron, A. C. and Trivedi, P. K. (2005). Microeconometrics: Methods and Applications. Cambridge University Press.

Damijan, J. P., Rojec, M., Majcen, B., and Knell, M. (2008). Impact of firm heterogeneity on direct and spillover effects of FDI: Micro evidence from ten transition countries. LICOS Discussion Paper 21808, LICOS - Centre for Institutions and Economic Performance, K.U. Leuven.

De Luca, G. (2008). SNP and SML estimation of univariate and bivariate binary-choice models. Stata Journal, 8(2):190-220.

Dixit, A. K. and Stiglitz, J. E. (1977). Monopolistic competition and optimum product diversity. The American Economic Review, 67(3):297-308.

Ethier, W. J. (1982). National and international returns to scale in the modern theory of international trade. The American Economic Review, 72(3):389-405.

Ferrantino, M. J. (1993). The effect of intellectual property rights on international trade and investment. Review of World Economics, 129(2):300?-331.

Gibson, M. and Graciano, T. (2011). Costs of starting to trade and costs of continuing to trade. working paper.

Ginarte, J. C. and Park, W. G. (1997). Determinants of patent rights: A cross-national study. Research Policy, 26(3):283-301.

Glass, A. J. and Saggi, K. (2002). Intellectual property rights and foreign direct investment. Journal of International Economics, 56(2):387-410.

Görg, H. and Greenaway, D. (2004). Much ado about nothing? Do domestic firms really benefit from foreign direct investment? The World Bank Research Observer, 19(2):171-197.

Grossman, G. M. and Helpman, E. (1991). Quality ladders and product cycles. The Quarterly Journal of Economics, 106(2):557?-586. 
Helpman, E. (1993). Innovation, imitation, and intellectual property rights. Econometrica, 61(6):1247-1280.

Instituto Nacional de Propiedad Industrial (INAPI). www.inapi.cl.

Javorcik, B. S. (2004a). Does foreign direct investment increase the productivity of domestic firms? In search of spillovers through backward linkages. The American Economic Review, 94(3):605-?627.

Javorcik, B. S. (2004b). The composition of foreign direct investment and protection of intellectual property rights: Evidence from transition economies. European Economic Review, 48(1):39?-62.

Javorcik, B. S. and Spatareanu, M. (2008). To share or not to share: Does local participation matter for spillovers from foreign direct investment? Journal of Development Economics, 85(1-2):194-217.

Kathuria, V. (2000). Productivity spillovers from technology transfer to Indian manufacturing firms. Journal of International Development, 12(3):343-369.

Keller, W. and Yeaple, S. R. (2009). Multinational enterprises, international trade, and productivity growth: Firm-level evidence from the United States. Review of Economics and Statistics, 91(4):821-831.

Lai, E. L.-C. (1998). International intellectual property rights protection and the rate of product innovation. Journal of Development Economics, 55(1):133-153.

Lee, J. Y. and Mansfield, E. (1996). Intellectual property protection and US foreign direct investment. The Review of Economics and Statistics, 78(2):181-186.

Levinsohn, J. and Petrin, A. (2003). Estimating production functions using inputs to control for unobservables. Review of Economic Studies, 70(3):317-341.

Lopez, R. A. (2008). Foreign technology licensing, productivity, and spillovers. World Development, 36(4):560-574.

Mansfield, E. (1994). Intellectual property protection, foreign direct investment, and technology transfer. International Finance corporation Discussion Paper No. 19. World Bank Washington, DC.

Markusen, J. R. and Venables, A. J. (1999). Foreign direct investment as a catalyst for industrial development. European economic review, 43(2):335-356.

Marschak, J. and Andrews, W. H. (1944). Random simultaneous equations and the theory of production. Econometrica, Journal of the Econometric Society, pages 143205. 
Maskus, K. E. and Penubarti, M. (1995). How trade-related are intellectual property rights? Journal of International Economics, 39(3-4):227-248.

Maskus, K. E., Saggi, K., and Puttitanun, T. (2005). Patent rights and international technology transfer through direct investment and licensing. In International Public Goods and the Transfer of Technology under a Globalized Intellectual Property Regime, pages 265-281. Cambridge University Press.

Montalvo, J. G. and Yafeh, Y. (1994). A microeconometric analysis of technology transfer: The case of licensing agreements of Japanese firms. International Journal of Industrial Organization, 12(2):227-244.

Moulton, B. R. (1990). An illustration of a pitfall in estimating the effects of aggregate variables on micro units. Review of Economics and Statistics, 72(2):334-338.

Nicholson, M. W. (2002). Intellectual property rights, internalization, and technology transfer. Working Paper 250.

Nunnenkamp, P. and Spatz, J. (2004). Intellectual property rights and foreign direct investment: A disaggregated analysis. Review of World Economics / Weltwirtschaftliches Archiv, 140(3):393-414.

Olley, G. S. and Pakes, A. (1996). The dynamics of productivity in the telecommunications equipment industry. Econometrica, 64(6):1263-1297.

Park, W. G. (2008). Intellectual property rights and international innovation. Frontiers of Economics and Globalization, 2:289-327.

Pavcnik, N. (2002). Trade liberalization, exit, and productivity improvements: Evidence from Chilean plants. The Review of Economic Studies, 69(1):245-276.

Rapp, R. T. and Rozek, R. (1990). Benefits and costs of intellectual property protection in developing countries. Working Paper 3.

Roodman, D. (2009). How to do xtabond2: An introduction to difference and system gmm in stata. Stata Journal, 9(1):86-136(51).

Smith, P. J. (2001). How do foreign patent rights affect U.S. exports, affiliate sales, and licenses? Journal of International Economics, 55(2):411-439.

Staiger, D. and Stock, J. H. (1997). Instrumental variables regression with weak instruments. Econometrica, 65(3):557-586.

Stock, J. H. and Yogo, M. (2002). Testing for weak instruments in linear IV regression. Working Paper 284, National Bureau of Economic Research.

Van Beveren, I. (2012). Total factor productivity estimation: A practical review. Journal of Economic Surveys, 26(1):98-128. 
Van Biesebroeck, J. (2003). Revisiting some productivity debates. Working Paper 10065, National Bureau of Economic Research.

Van Biesebroeck, J. (2007). Robustness of productivity estimates. The Journal of Industrial Economics, 55(3):529-569.

Vernon, R. (1966). International investment and international trade in the product cycle. The Quarterly Journal of Economics, 80(2):190-207.

World Trade Organization. Intellectual property: Protection and Enforcement. http://www.wto.org

Yang, G. and Maskus, K. E. (2001). Intellectual property rights, licensing, and innovation in an endogenous product-cycle model. Journal of International Economics, $53(1): 169-187$.

Zanatta, M., Strachman, E., Carvalho, F., Varrichio, P. C., Camillo, E., and Barra, M. (2008). National policies to attract FDI in R\&D. An assesment of Brazil and selected countries. Technical Report 69, United Nations University - World Institute for Development Economics Research.

Canavire, G. A. Saravia, and F. Rios-Avila. (2017). Intellectual Property Rights, Foreign Direct Investment and Economic Freedom Global Economy Journal 


\section{Appendix}

\section{A. FDI in Chile}

Table 6: FDI by Economic Sector 1998-2007 Under DL600 (US Millions of dollars)

\begin{tabular}{|c|c|c|c|c|c|c|c|c|c|c|}
\hline Sub-Sector/period & 1998 & 1999 & 2000 & 2001 & 2002 & 2003 & 2004 & 2005 & 2006 & 2007 \\
\hline Agriculture and fanning & 13 & 21 & 23 & 10 & 2 & 0 & 0 & 1 & 3 & 1 \\
\hline Forestry and logging & 38 & 16 & 4 & 1 & 1 & 1 & 0 & 7 & 17 & 108 \\
\hline Fishing and aquaculture & 8 & 0 & 92 & 5 & 0 & 10 & 0 & 0 & 0 & 11 \\
\hline Coal mining & 0 & 0 & 0 & 0 & 0 & 0 & 0 & 0 & 0 & 0 \\
\hline Petroleum and natural gas production & 0 & 0 & 0 & 0 & 0 & 0 & 0 & 0 & 0 & 0 \\
\hline Metal ore mining & 2,308 & 1,244 & 161 & 1,043 & 1,854 & 313 & 334 & 507 & 317 & 68 \\
\hline Other mining & 161 & 92 & 73 & 94 & 149 & 80 & 16 & 82 & 809 & 236 \\
\hline Food, beverages and tobacco & 67 & 407 & 44 & 273 & 29 & 55 & 56 & 186 & 70 & 20 \\
\hline Textiles and leather industries & 6 & 19 & 4 & 4 & 2 & 0 & 18 & 1 & 0 & 0 \\
\hline Wood and wood products & 30 & 24 & 27 & 7 & 12 & 6 & 1 & 3 & 2 & 7 \\
\hline Paper products, printing and publishing & 56 & 23 & 2 & 51 & 37 & 119 & 81 & 1 & 2 & 16 \\
\hline Chemical, rubber and plastics & 308 & 232 & 94 & 344 & 32 & 0 & 271 & 1 & 0 & 7 \\
\hline Non-Metallic mineral products & 16 & 60 & 9 & 24 & 1 & 1 & 2 & 1 & 21 & 3 \\
\hline Basic metal industries & 21 & 37 & 58 & 86 & 99 & 1 & 0 & 0 & 0 & 0 \\
\hline Metal products, machinery and equipment & 27 & 30 & 14 & 19 & 6 & 1 & 0 & 6 & 0 & 16 \\
\hline Other manufacturing industries & 1 & 0 & 0 & 3 & 0 & 0 & 0 & 0 & 0 & 0 \\
\hline Electricity, gas and steam & 481 & 3,971 & 858 & 861 & 223 & 114 & 2,193 & 33 & 1,141 & 64 \\
\hline Water works and supply & 14 & 569 & 1 & 47 & 250 & 36 & 0 & 65 & 65 & 105 \\
\hline Construction & 279 & 211 & 29 & 164 & 138 & 29 & 119 & 8 & 9 & 2 \\
\hline Wholesale and retail trade & 190 & 86 & 120 & 114 & 72 & 43 & 17 & 3 & 19 & 263 \\
\hline Restaurants and hotels & 31 & 3 & 32 & 51 & 4 & 5 & 0 & 5 & 2 & 1 \\
\hline Transport and storage & 132 & 26 & 15 & 35 & 5 & 55 & 24 & 55 & 172 & 16 \\
\hline Communication & 91 & 388 & 856 & 1,246 & 331 & 283 & 1,402 & 515 & 65 & 66 \\
\hline Banking & 393 & 787 & 189 & 60 & 31 & 13 & 0 & 7 & 13 & 84 \\
\hline Investment companies & 391 & 143 & 74 & 40 & 16 & 28 & 7 & 105 & 107 & 110 \\
\hline Investment funds & 0 & 0 & 2 & 13 & 3 & 3 & 1 & 4 & 3 & 2 \\
\hline Risk capital investment funds & 8 & 0 & 0 & 0 & 0 & 0 & 0 & 12 & 1 & 5 \\
\hline Other financial services & 29 & 20 & 8 & 8 & 9 & 0 & 3 & 5 & 0 & 47 \\
\hline Insurance & 702 & 208 & 90 & 265 & 20 & 4 & 49 & 107 & 23 & 10 \\
\hline Real estate activities & 37 & 24 & 8 & 21 & 3 & 0 & 19 & 7 & 57 & 13 \\
\hline Engineering and business services & 69 & 26 & 66 & 60 & 39 & 21 & 15 & 55 & 93 & 71 \\
\hline Sewage, sanitation and similar services & 20 & 471 & 2 & 3 & 1 & 1 & 0 & 2 & 0 & 0 \\
\hline Social and related community services & 0 & 0 & 11 & 44 & 7 & 10 & 0 & 0 & 167 & 3 \\
\hline Recreation and cultural services & 88 & 81 & 68 & 25 & 5 & 2 & 5 & 16 & 3 & 2 \\
\hline Other services & 25 & 8 & 4 & 2 & 0 & 0 & 0 & 0 & 0 & 0 \\
\hline Total Manufacturing sector & 530 & 833 & 253 & 812 & 218 & 184 & 430 & 199 & 95 & 69 \\
\hline As $\%$ of total & 9. & 9. & 8. & 16. & 6. & 15. & 9. & 11. & 3.00 & 5. \\
\hline Total per period & 6,038 & 9,229 & 3,039 & 5,023 & 3,381 & 1,236 & 4,637 & 1,799 & 3,181 & 1,359 \\
\hline
\end{tabular}


Table 7: Distribution of Firms according to Sector

\begin{tabular}{|c|c|c|}
\hline !SIC rev.3 at 2-digit level & OPbervations & Description \\
\hline 15 & 11,217 & Manufacture of food products and beverages \\
\hline 17 & 1,724 & Manufacture of textiles \\
\hline 18 & 1,841 & Manufacture of wearing apparel; dressing and dyeing of fur \\
\hline 19 & 938 & $\begin{array}{l}\text { Tanning and dressing of leather; manufacture of luggage, } \\
\text { handbags, saddlery, harness and footwear }\end{array}$ \\
\hline 20 & 2,432 & $\begin{array}{l}\text { Manufacture of wood and of products of wood and cork, except } \\
\text { furniture; manufacture of articles of straw and plaiting materials }\end{array}$ \\
\hline 21 & 1,050 & Manufacture of paper and paper products \\
\hline 22 & 1,796 & Publishing, printing and reproduction of recorded media \\
\hline 24 & 2,127 & Manufacture of chemicals and chemical products \\
\hline 25 & 2,219 & Manufacture of rubber and plastics products \\
\hline 26 & 1,913 & Manufacture of other non-metallic mineral products \\
\hline 27 & 920 & Manufacture of basic metals \\
\hline 28 & 2,567 & $\begin{array}{l}\text { Manufacture of fabricated metal products, except machinery } \\
\text { and equipment }\end{array}$ \\
\hline 29 & 1,953 & Manufacture of machinery and equipment n.e.c. \\
\hline 30 & 12 & Manufacture of office, accounting and computing machinery \\
\hline 31 & 515 & Manufacture of electrical machinery and apparatus n.e.c. \\
\hline 32 & 55 & $\begin{array}{l}\text { Manufacture of radio, television and communication equipment } \\
\text { and apparatus }\end{array}$ \\
\hline 33 & 212 & $\begin{array}{l}\text { Manufacture of medical, precision and optical instruments, } \\
\text { watches and clocks }\end{array}$ \\
\hline 34 & 512 & Manufacture of motor vehicles, trailers and semi-trailers \\
\hline 35 & 323 & Manufacture of other transport equipment \\
\hline 36 & 1,700 & Manufacture of furniture; manufacturing n.e.c. \\
\hline
\end{tabular}




\section{B. Descriptive Statistics and Results}

Table 8: Descriptive Statistics (Tech Vs. Non-tech Firms)

\begin{tabular}{|c|c|c|c|c|c|c|c|c|}
\hline \multirow[t]{2}{*}{ Variable } & \multicolumn{4}{|c|}{ Non-Tech Plants (33,620 plants) } & \multicolumn{4}{|c|}{ Tech Intensive plants $(2,406$ plants $)$} \\
\hline & Mean & $\mathrm{SD}$ & Min & Max & Mean & $\mathrm{SD}$ & Min & $\operatorname{Max}$ \\
\hline Capital Stock & 2255. & 24182. & 0 & $2 . \mathrm{E}+06$ & 7593. & 46920. & 0 & 1.E+06 \\
\hline$\%$ Domesic Capital & 96. & 17. & 0 & 100 & 81. & 38. & 0 & 100 \\
\hline$\%$ Foreign Capital & 4. & 17. & 0 & 100 & 19. & 38. & 0 & 100 \\
\hline Value Added & 2566. & 21593. & $-1 . \mathrm{E}+05$ & $2 . \mathrm{E}+06$ & 9848. & 64529 . & -6443. & $2 . \mathrm{E}+06$ \\
\hline Sale Of Production & 4230. & 27287. & 0 & 2.E+06 & 15164. & 1. $\mathrm{E}+05$ & 0 & 2. $\mathrm{E}+06$ \\
\hline License And Foreign Assistance & 5 . & 83. & 0 & 5578. & 59. & 497. & 0 & 11864. \\
\hline Income Due To Exports & 1696. & 17559. & 0 & 1. $\mathrm{E}+06$ & 2930. & 20472. & 0 & 4. $\mathrm{E}+05$ \\
\hline Number of Skilled Workers & 14. & 56. & 0 & 2691 & 22. & 72. & 0 & 1057 \\
\hline Skilled/Unskilled workers ratio & 0.69 & 4. & 0 & 287 & 0.97 & 5 . & 0 & 139 \\
\hline Skillid/Total workers ratio & 0.24 & 0.3 & 0 & 1 & 0.24 & 0.29 & 0 & 1 \\
\hline
\end{tabular}

Table 9: Foreign Presence and Licensing

\begin{tabular}{|c|c|c|c|c|c|c|}
\hline & $\overline{(1)}$ & $\overline{(2)}$ & $\overline{(3)}$ & $\overline{(4)}$ & $\overline{(5)}$ & $\overline{(6)}$ \\
\hline Variables & fdikstock & fdikstock & fdikstock & license & license & license \\
\hline WEF IPR. $\mathrm{x}$ Tech & & & $\begin{array}{l}-0.17^{*} \\
(0 .)\end{array}$ & & & $\begin{array}{l}0 . \\
(0 .)\end{array}$ \\
\hline Fraser IPR x Tech & & $\begin{array}{l}-0.03^{* * *} \\
(0 .)\end{array}$ & & & $\begin{array}{l}0.11^{* *} \\
(0 .)\end{array}$ & \\
\hline Dummy IPR. x Tech & $\begin{array}{l}\text { M. } 09^{* * * *} \\
(0 .)\end{array}$ & & & $\begin{array}{l}0.31^{* *} \\
(0 .)\end{array}$ & & \\
\hline Observations & 748 & 748 & 748 & 748 & 748 & 748 \\
\hline R.-squared & 0.74 & 0.74 & 0.74 & 0.88 & 0.88 & 0.87 \\
\hline Time Dummies & YES & YES & YES & YES & YES & YES \\
\hline Industry Dummies & YES & YES & YES & YES & YES & YES \\
\hline
\end{tabular}


Table 10: Random Effects Probit

\begin{tabular}{|c|c|c|c|}
\hline & $(1)$ & $(2)$ & $(3)$ \\
\hline Variables & owner & owner & owner \\
\hline WEF IPR x Tech & $\begin{array}{l}0.84^{* * *} \\
(0 .)\end{array}$ & & \\
\hline Fraser IPR x Tech & & $\begin{array}{l}0.76^{* * *} \\
(0 .)\end{array}$ & \\
\hline Dummy IPR x Tech & & & $\begin{array}{l}0.70^{* * *} \\
(0 .)\end{array}$ \\
\hline iprwef & $\begin{array}{l}0.73 \\
(1 .)\end{array}$ & & \\
\hline iprf & & $\begin{array}{l}-0.35^{* * *} \\
(0 .)\end{array}$ & \\
\hline dipr & & & $\begin{array}{l}-0.69^{* * *} \\
(0 .)\end{array}$ \\
\hline Real Exchange Rate & $\begin{array}{l}0 . \\
(0 .)\end{array}$ & $\begin{array}{l}\text { M.04** } \\
(0 .)\end{array}$ & $\begin{array}{l}\text { M. } 04^{* *} \\
(0 .)\end{array}$ \\
\hline Average Size & $\begin{array}{l}0.79^{* * *} \\
(0 .)\end{array}$ & $\begin{array}{l}0.80^{* * *} \\
(0 .)\end{array}$ & $\begin{array}{l}0.86^{* \prime \prime} \\
(0 .)\end{array}$ \\
\hline Inflation & $\begin{array}{l}0 . \\
(0 .)\end{array}$ & $\begin{array}{l}0.09 \\
(0 .)\end{array}$ & $\begin{array}{l}0.06 \\
(0 .)\end{array}$ \\
\hline Observations & 37,254 & 37,254 & 37,254 \\
\hline Number of id & 8,287 & 8,287 & 8,287 \\
\hline Time Dummies & YES & YES & YES \\
\hline
\end{tabular}

Standard errors in parentheses

*** $\mathrm{p}<0.01,{ }^{* *} \mathrm{p}<0.05,{ }^{*} \mathrm{p}<0.1$ 